\title{
After the Revolution in Corporate Law
}

\author{
Roberta Romano
}

Corporate law is a field that underwent as thorough a revolution in the I980s as can be imagined, in scholarship and in practice, methodology, and organization. The term "revolution" is invoked all too often in popular culture, but as this article will suggest, it is entirely apt in this case. The revolution in corporate law has been so thorough and profound that those working in the field today would have considerable difficulty recognizing what it was like twenty-five to thirty years ago. I was fortunatc to have started out in law teaching in that turbulent, transitional era, for it was an exciting time to be in corporate law.

This revolution has produced one of the more interdisciplinary fields of law. One measure of the field's transformation is that the submissions to the annual meeting of the American Law and Economics Association, which now number in the hundreds, are overwhelmingly dominated by corporate law scholars; they could fill up most of the program, were the Association not to limit the number of corporate-law-related scssions to encourage broader program coverage and participation. The integration of finance and economic theory into legal analysis is true not of corporate law scholarship alone but has been extended to practice and judicial decisionmaking.

This article first explains why the revolution in corporate law in the rg8os was not fortuitous: it followed a revolution in corporate finance and the theory of the firm, and was mid-wived in a period of dynamic innovation in corporate transactions. The article then touches briefly on the course of the revolution, and how it reached all aspects of corporate law-from practitioners to academics, to regulatory agencies and U.S. and state Supreme Court opinions. It concludes by discussing the implications of the sea change in corporate law scholarship and practice for legal education in the twenty-first century, especially for law schools where research plays a central role.

Roberta Romano is the Oscar M. Ruebhausen Professor of Law and Director of the Yale Law School Center for the Study of Corporate Law, Research Associate, National Bureau of Economic Research and Fellow, European Corporate Governance Institute. This article is based on the Oscar M. Ruebhausen Inaugural Lecture given at Yale Law School on September 21, 2005. My thanks to the editors for helpful sggestions. 


\section{Background to the Revolution in Corporate Law}

In the ig6os, corporate law was an ossified, stagnant field. Dean Bayless Manning aptly summed up the situation in 1962 : "Corporation law, as a field of intellectual effort, is dead in the United States... We have nothing left but our great empty corporation statutes-towering skyscrapers of rusted girders, internally welded together and containing nothing but wind."' Most state corporation codes at the time were relics of the turn of the century; Delaware was to modernize its code in 1967 , and the first revision of the Model Business Corporation Act was completed in 1969 . The state of corporate law scholarship was not much different from that of corporation statutes.

We can trace the intellectual origin of what would become the new paradigm for corporate law to a pioneering article on mergers published in 1965 by Henry Manne only a few years after Manning's comment. ${ }^{2}$ The article coined the term "the market for corporate control," and challenged the conventional view of mergers as anticompetitive by contending (I) that control changes in mergers played an efficiency-enhancing role by replacing poorly performing managers and (2) that takeovers were preferable to mergers as an acquisition device because they avoided management's transactional veto, which was required by merger statutes. But that article appeared in the Journal of Political Economy (a leading economics journal) and not in a law review, and Manne's contribution went largely unrecognized in corporate law scholarship for close to two decades.

The lag in the acknowledgment of the significance of Manne's contributions was no accident. The perspective of legal scholars on corporate law in the ig6os and ig7os differed dramatically from our contemporary understanding: as Judge Ralph Winter described it, corporate law back in those days was treated as a "species of consumer protection law," based on the perception that managers ran corporations, under the aegis of state corporate law, with the objective of exploiting shareholders, and that neither the states nor markets could be trusted to constrain managers or otherwise protect investors. ${ }^{3}$ In line with this view, eighty law professors (which would appear to have been the deci-

I. Bayless Manning, The Shareholders'Appraisal Remedy: An Essay for Frank Cokcr, 72 Ya le L.J. 223, 245 n.37 (1962). William Carney also summarizes the state of the field as having reached an intellectual dead-end in a tribute to Henry Manne, in William Carney, The Legacy of the "Market for Corporate Control" and the Origins of the Theory of the Firm, $5^{\circ}$

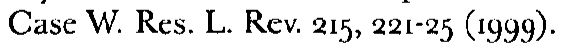

2. Henry G. Manne, Mergers and the Market for Corporate Control, 73 J. Pol. Econ. 11o $\left(19^{6}\right)$.

3. Ralph K. Winter, Foreword to Roberta Romano, The Genius of American Corporate Law ix (Washington, D.C, 1993). See also Carney, supra note I. For Manne's description of his experience at the time, see Henry G. Manne, How Law and Economics was Marketed in a Hostile World: A Very Personal History, in Francesco Parisi and Charles K. Rowley eds., The Origins of Law and Economics: Essays by the Founding Fathers 309, $3^{11-12}$ (Northampton, Mass., 2005). 
sive majority of corporate law specialists) signed a petition in 1976 advocating Congress' adoption of a national corporation law to preempt the states.

Only one year later Winter challenged that view in an article that identified fundamental analytical flaws in the conventional understanding embodied in the law professors' petition. In that understanding, state law was a "race for the bottom" that facilitated managers' exploitation of shareholders. ${ }^{4}$ The article contends that managers would not select legal regimes that systematically disadvantaged investors because that would raise their cost of capital compared to competitors located in regimes more favorable to investors, and consequently diminish their career prospects (they risked being fired as their firms went bankrupt or were acquired). Like Henry Manne's article on mergers, Winter's economic analysis of the production of state corporate law went against the grain of the prevailing understanding and, like Manne's, Wintcr's article was largely ignored by the academy. Winter and Manne were truly voices in the wilderness and their analyses were widely regarded as "unsound" by their contemporaries. Today, decades later, their approach is mainstream corporate law, and serves as a starting point of analyses by advocates and critics of mergers and acquisitions and of state corporate law.

This transformation of the discourse is part and parcel of a revolution that effected a paradigm shift in how we understand corporations, business transactions, and the legal rules governing them, that took place in the decades following Manne's and Winter's publications. Manne and Winter were not any less skillful analysts or policy advocates than the generation of scholars that followed. Rather, the methodology that would have enabled Manne and Winter to compel their contemporaries to confront (if not accept) their analyses by enabling them to demonstrate that their hypotheses regarding how managers behaved and how acquisitions and the market for control worked to discipline managers were correct, was not in place when those articles were written. The appropriate methods were not yet developed. Only later could their hypotheses be tested and their insights fully appreciated. The impetus for their contemporaries to update their prior beliefs concerning regulation was therefore lacking. Furthermore, the new transactions that underscored the intellectual vacuousness of the then-dominant doctrinal paradigm did not yet exist. It was only after those methodological and transactional developments that the revolution took hold.

\section{The Revolution in Corporate Finance}

There are three distinct strands to the story of the transformation of corporate law in the latter half of the twentieth century. An important milestone was the pioneering casebook on corporate finance by Victor Brudney and Marvin

4. Ralph K. Winter, State Law, Shareholder Protection, and the Theory of the Corporation, $6 \mathrm{~J}$. Leg. Stud. 25I (1977). 
Chirelstein, 5 which introduced a new methodology, modern finance, into the business law curriculum.

Chirelstein had been dragooned by Dean Eugene Rostow into teaching what was then called Business Units II when he arrived at Yale Law School in 1965 from Rutgers, where he and Brudney had been colleagues. What was there to do with a course that consisted "entirely of case-annotations for commonly used bond indentures and other boiler-plate documents," and was "the most boring and insignificant course ever offered anywhere at any time in any language" (as Chirelstein put it)? The rg6os were a fervent period in the theoretical development of finance, which had previously been an unexciting, descriptive field involving financial ratio analysis and rules of thumb. Finance had been as dead a field as corporate law, but no longer. Reading the Journal of Finance in those days was certainly more intellectually stimulating than reading the dreary provisions in bond indentures, and Chirelstein thought that was just the thing to spice up Business Units II.

Brudney and Chirelstein were intrigued by the notions of random walk and efficient markets buzzing around in the air, and what impact these concepts would have on the liability and property rules relating to corporate law. They put these ideas together into a casebook published in 1972 . The casebook could not, however, have appeared much earlier because of the relative infancy of the tools of modern finance. A brief chronology of the theoretical breakthroughs in finance conveys the point:

- $\quad$ 1952: modern financial theory was born with the publication of Harry Markowitz's dissertation, which developed what is referred to as the portfolio theory of investment decisionmaking, or portfolio selection, introducing a security's risk, as well as its return, into the decisional mix.

- $\quad 1958$ and ig62: Franco Modigliani and Merton Miller, referred to in the literature as " $M$ \& $M$," developed irrelevance theories of firm capital structure and valuation launching a debate that continues to this day.

- $\quad$ I964-65: John Lintner and William Sharpe specified the capital asset pricing model, better known in the literature as the CAPM, a model for measuring risk. ${ }^{6}$ This important development made Markowitz's portfolio theory more tractable-one could solve for the optimal portfolio without complex computer programming-and it put the theory into an empirically testable form, which is critical for a theory's acceptability.

In 199o, Markowitz, Miller, and Sharpe shared the Nobel memorial prize in economics (Modigliani had won the prize years earlier). With that award, we

5. Victor Brudney and Marvin A. Chirelstein, Cases and Materials on Corporate Finance (Mineola, N.Y., 1972).

6. Jack Treynor also independently discovered the CAPM in a paper written in 1962 , but that work was not recognized as such until many years after the publications by Sharpe and Lintner; even Treynor did not recognize the importance of the insight in his paper at the time it was written. See, e.g., Perry Mehrling, Fischer Black and the Revolutionary Idea of Finance 59, 73 (Hoboken, N.J., 2005). 
can say that finance had arrived. The relative recency of the award, indicating acceptance of finance's contribution to economics, is a further reminder of how trailblazing the Brudney and Chirelstein casebook was, in its taking an "infant" discipline as the mode of analyzing the key concerns of corporate law.

Just as the CAPM was an important step in the progress of finance theory because of its testability, a major component of finance research consists of testing the accuracy of pricing models. ${ }^{7}$ In this regard, finance differs from many other fields in economics because it has a decidedly empirical focus. The most important empirical finance methodology for policy purposes consists of what the literature rcfers to as event studies, which measure the effect of specified "events" on stock prices.

Event studies were developed in conjunction with testing the concept of an cfficient market, the idea that market prices incorporate information; in an efficient market, abnormal profits cannot be made by trading on public information. The modern literature on efficient markets dates from an article by Paul Samuelson published in 1965 and reached a broad audience with the publication of Eugene Fama's classic survey in $1970 .^{8}$ The first modern event studies were published by accountants in 1968 and by financial economists in I969; this constitutes the final finance innovation of particular relevance to the revolution in corporate law. Event studies are now a cottage industry, literally hundreds having been published in nearly all finance journals. They provided a methodology for testing Manne's and Winter's hypotheses regarding the market for control and corporate charters. In that regard their development was as critical a component in the revolution in corporate law as that of the finance theory they were testing, and they have had an important impact on the course of corporate law and corporate governance. The widespread application of the technique did not occur in academia, however, until the burst of takeover activity in the rg8os.

In a nutshell, the major breakthroughs in modern finance were still quite recent and were not fully assimilated in the finance profession when the Brudney and Chirelstein casebook was published and began the effort to connect the learning of modern finance with business law. The effort simply could not have begun much earlier. It should also be evident that the intellectual roots of modern corporate law scholarship are quite distinct from the standard microeconomic methodology applied in the law and economics literature. This is an important distinction to which I will return when considering the implications of the revolution for legal education and scholarship.

7. In a well-known critique of the testability of the CAPM, Richard Roll emphasized that the market portfolio is unobservable and hence tests are of the mean-variance efficiency of a proxy and not the true market portfolio, but subsequent empirical and theoretical work has indicated that his concern is not a problem in practice. See John Y. Campbell et al., The Econometrics of Financial Markets 213-15 (Princeton, 1997).

8. John Campbell, Andrew Lo, and Craig MacKinlay sketch the modern development of the efficient market hypothesis and the event study methodology. See id. at 20, $5^{\circ}$. 


\section{A Parallel Revolution in Microeconomics: The New Theory of the Firm}

Paralleling the intellectual revolution that occurred in modern finance in the Ig6os, a similar revolution was occurring in economics regarding the theory of the firm in the mid-rg7os. This is the second strand contributing to the revolution in corporate law.

In the mid-I970s, a number of economists attempted to delve inside the black box of the firm as it was characterized in neo-classical economics (the firm as a production function), and to understand it on a micro-analytic level. Two lines of development in this research agenda have had a lasting impact on the thinking of corporate law academics. The first is transaction cost economics. This research is associated most closely with Oliver Williamson, whose foundational book on business organization, Markets and Hierarchies, was published in $1975 .{ }^{9}$ The second is the agency costs theory of the firm. This line of research was introduced in 1976 by Michael Jensen and William Meckling, who, working from the corporate finance literature, gave systematic economic content to the much earlier key observation of Adolf Berle and Gardiner Means in 1932, that ownership was separated from control in the modern U.S. corporation. ${ }^{\circ}$ Both of these theoretical approaches for analyzing firms were mathematicized and refined by economists in the ensuing decades and the microanalytic approach to the firm has come to permeate the microeconomics and industrial organization literatures.

\section{Revolution in Corporate Practice: Doing Deals in the Era of the Hostile Takeover}

The third critical strand that, when conjoined with the analytical tools of modern finance and the new theory of the firm, produced a full-blown revolution in corporate law, came from the world of corporate practice: an explosion in innovative deals. Just as the new theoretical developments in finance were rapidly being integrated into the business school curriculum, there was a boom in acquisitive transactions of public corporations and a new dynamic in control changes emerged. This was the era of the hostile takeover, undertaken through a novel, highly leveraged structure, made possible by innovations in transaction financing developed by Michael Milken and his investment bank, Drexel Burnham Lambert.

Before Milken's new issue operation began, the junk bond market consisted principally of downgraded debt of established firms. Milken reinvented junk bonds as a financing mechanism for new ventures, and his support of a market for the new issues that he placed, enabled small firms to acquire large ones

9. Oliver E. Williamson, Markets and Hierarchies: Analysis and Antitrust Implications (New York, 1975). This line of research works out of a now-celebrated article that was all but ignored for decades, Ronald Coase's $193^{2}$ article on the nature of the firm, for which, along with his article on social costs, he received the Nobel memorial prize in economics in 1991.

Io. Michael C. Jensen and William H. Meckling, Theory of the Firm: Managerial Behavior, Agency Costs, and Ownership Structure, 3J. Fin. Econ. 305 (1976). 
previously considered impervious to unsolicited bids, and changed the way business was conducted in the United States. The use of such financing for hostile takeovers was in fact a relatively small segment of the high-yield market created by Milken, although no doubt the most visible part; the instruments provided relatively inexpensive financing for many small and mid-sized firms in what were then new and underdeveloped sectors of the economy-providers of cellular phones, cable television, and personal computers, among others."

The new financing techniques catapulted Drexel, which had been a sleepy investment bank, into a prominent and highly profitable role. ${ }^{12}$ There was also a parallel rapid growth in law firms specializing in mergers and acquisitions transactions, working on the hostile bidder side as well as on the defense.

More importantly, lawyers and courts needed new ways to talk and think about, and respond to, these novel transactions: for example, what should be the fiduciary standard for the actions of managers and boards of directors in response to a hostile bid? How should the fairness of the price in a negotiated or hostile acquisition be evaluated? Should shareholder consent to actions that could be used to thwart takeovers be discounted because that consent had been granted before takeovers had become common and those actions took on a defensive use? More concretely, how could an effective defense be structured while preserving flexibility to entertain alternative bids? The theoretical developments in finance and in the theory of the firm literature provided the language and the analytical tools to address a host of challenging legal issues.

\section{The Transformation of Corporate Law}

As the decade progressed and deals continued apace with the transaction scale ever-increasing, the profitability of mergers and acquisitions practice correspondingly increased, attracting the attention of more established investment banks and law firms. As the old line firms entered the takeover business, the nature of business law practice was fundamentally reconfigured. Since the best scholarship in corporate law is in a symbiotic relation with real world transactions, that scholarship followed suit.

Modern finance and the new economic theories of the firm provided the analytical tools for understanding the new deals transforming corporate law practice in the I98os, and how the legal system should respond to those challenges. A groundbreaking article by Frank Easterbrook and Daniel Fischel in I98I, which advocated a change in the fiduciary standard applied in takeovers, integrated the finance and agency costs literature into a theory of takeovers

II. See, e.g., Glenn Yago, Junk Bonds: How High Yield Securities Restructured Corporate America (New York, 1991).

12. The firm disappeared after the SEC filed civil charges against it and Milken for securities fraud and it pled guilty to criminal charges, but its novel techniques survived and became ubiquitous. 
informed by Manne's central ${ }^{1} 6_{5}$ insight. $^{13}$ In contrast to the period when Manne was writing the timing was ripe for these ideas to take root in mainstream discourse; the old doctrinal mode of analysis was abandoned as hopelessly inadequate to the task. Modern finance and the economic theory of the firm enabled a new generation of scholars to craft rationales for advocating significant alterations of the fiduciary standards courts applied in acquisitions. They were able to draw support in that endeavor from a sizeable empirical literature that demonstratcd significant gains to sharcholders from hostile takeovers. Although the courts never came over entirely to the dominant perspective in the academic literature (which advocated restrictions on management responses to hostile bids), that literature was without doubt one of many factors affecting courts' perception of takeovers, and, in particular, the Delaware Supreme Court's 1985 revision of the fiduciary standard applicable in the hostile takeover context. ${ }^{14}$

It is important to highlight the symbiotic relationship between practice and legal scholarship as it was developing in the Ig8os, as this relation is a critical factor to which I will return when discussing implications. The generation of corporate law scholars coming of age in the cra of hostilc takeovers cmbraced the interdisciplinary approach that had distanced Manne and Winter from their contemporaries. At the same time, Wall Street was being populated by individuals, often referred to as "quants," who were trained in the new asset pricing models and quantitative methods. Investment banks also became heavily involved in all stages of the takeover process; takeovers were lucrative and the banks offered needed valuation skills. Law firms followed suit, becoming increasingly conversant in finance as wcll, working alongside the investment banks to devise more effective strategies for companies' defenses and responses to defenses, and to ensure that complex merger documents embodied understandings regarding warranties and representations, and protected buyers' investments and sellers' fiduciary obligations. This was a period of ferment and innovation; lawyers' creative ingenuity in fashioning defenses was reflected in a new colorful terminology of crown jewels, white knights, bear hugs, greenmail, scorched earth and Pacman defenses, golden parachutes, poison pills, and the

13. Frank H. Easterbrook and Daniel R. Fischel, The Proper Role of a Target's Management in Responding to a Tender Offer, 94 Harv. L. Rev. II6r ( $198 \mathrm{r}$ ). Parallel contributions were made by Lucian Bebchuk and Ronald Gilson, who engaged in a debate with Easterbrook and Fischel over the proper extent of management responses to bids in the November 1982 issue of the Stanford Law Review.

14. The literature was cited in the Delaware Supreme Court's decision to enhance judicial scrutiny, although the Court also explicitly rejected Easterbrook and Fischel's advocacy of a rule of managerial passivity: Unocal Corp. v. Mesa Petroleum Co., 493 A. 2d 946, 954-955 nn. 9 \& $10\left(198_{5}\right)$. For a discussion of the many factors, political, social, and economic, affecting the Delawarc courts' takcover jurisprudence, sec Jeffrey N. Gordon, Corporations, Markets, and Courts, 91 Colum. L. Rev. 1931 (r991). 
like. Notwithstanding considerable efforts to derail these developments legislatively, the new transactions were here to stay. ${ }^{15}$

In academia, the economic analyses of Manne and Winter received empirical support, as event studies tested the hypotheses advanced by Manne on merger motivations and by Winter on state corporate law. The studies' findings were most consistent with the efficiency (managerial disciplining) rather than anticompetitive explanation of mergers, and the pro-investor (race to the top) rather than manager exploitation (race to the bottom) interpretation of state law, the positions espoused by Manne and Winter that had cast them as intellectual outliers earlier. ${ }^{16}$ This is not to say that contributors to the field did not, or do not, continue to have strong substantive policy disagreements or dispute the interpretation or significance of empirical findings. They did and do. But there was now a consensus on the appropriate mode of analysis-that it should be informed by finance and the new economic theories of the firm. Although prominent practitioners questioned the use of economics in the academic literature, disputing conclusions as wrong-headed, their practice demanded that they too become increasingly conversant in finance and economics, and they did, as they worked on deals in tandem with investment bankers.

The influence of finance theory did not end with its impact on corporate practice and legal scholarship, but extended to the courts and U.S. Securities and Exchange Commission. In the ig8os, several remarkable judicial opinions used the learning of modern finance in fashioning legal rules. In 1985 , the Delaware Supreme Court revised the longstanding methodology used for appraisal (the statutory right to receive the "fair" value for shares acquired in a merger as determined by a court) to include any method generally accepted by the financial community (by which the court meant modern finance) ${ }^{17}$ In I988, the U.S. Supreme Court accepted the efficient market hypothesis as the basis for demonstrating proof of reliance in federal securities fraud litigation. ${ }^{18}$ Following the Supreme Court's lead, the SEC began applying the event study technique in insider trading cases to identify liability (whether false disclosures or omissions were material) and to measure damages. ${ }^{19}$ In addition, through-

15. For a discussion of state and federal efforts to regulate hostile takeovers see, e.g., Roberta Romano, The Future of Hostile Takeovers: Legislation and Public Opinion, 57 U. Cin. L. Rev. 457 (1988).

16. Sce, e.g., Espen Eckbo, Horizontal Mergers, Collusion and Stockholder Wealth, ir J. Fin. Econ. 24I ( 1983$)$; Peter Dodd and Richard Leftwich, The Market for Corporate Charters: "Unhealthy Competition" vs. Federal Regulation, 53 J. Bus. 259 (1980).

17. Weinberger v. UOP Inc., 497 A.2d 792 (1985). Rutheford Campbell tabulates how the methods applied in Delaware appraisal cases thereafter changed considerably, producing more economically rational valuations. Rutheford Campbell, The Impact of Modern Finance Theory in Acquisition Cases, 53 Syracuse L. Rev. I (2003).

18. Basic Inc. v. Levinson, 485 U.S. 224 (1988).

19. Two former SEC economists pinpoint the initial cases in which the SEC made usc of the methodology as occurring in 1988 and 1989 , citing Basic v. Levinson as providing the "intellectual basis" for the application. Mark L. Mitchell and Jeffry M. Netter.The Role of Financial 
out the r 980 it opposed managers' defensive tactics against hostile bids, influenced by the finance literature, which had assimilated Manne's understanding of the market for control. ${ }^{20}$

Modern finance and the economic theory of the firm offered analytical insight beyond takeovers. Easterbrook and Fischel's book, The Economic Structure of Corporate Law, published in I99I ${ }^{21}$ coinciding with the decline in takeover activity at the end of the Ig8os, synthesized the whirlwind changes in the state of knowledge, to which they had significantly contributed. It is the other bookend to the Brudney and Chirelstein casebook, delineating the time frame within which the field was transformed. The book's publication marked the end of the revolutionary phase in corporate law scholarship, as modern finance and economics had come to be the conventional analytical approach to corporate law.

The most important reason for the adoption of the new analytical approach was, no doubt, the beauty of the intellectual fit. Modern finance had become the language of business, and lawyers needed to be knowledgeable about it in order to serve their clients. As takeovers flourished, those deals set the teaching and research agenda, and finance and the theory of the firm provided the tools for analyzing the deals and the novel legal issues they raised. In addition, the metric of event studies, the impact of corporate policies on stock prices, meshed well for policy analysis within the framework of U.S. corporate law, which imposes fiduciary obligations on directors to act for the benefit of the shareholders. Finally, the Anglo-American legal tradition has been instrumental in its approach, and this jurisprudential perspective is most consonant with interdisciplinary research grounded in positive theories of behavior: because the objective of the law is to affect behavior, a theory that can predict behavior is essential to get the incentives right. Modern finance and the theory of the firm offered plausible theories of investor and manager behavior and therefore quickly came to be pervasive in analyses of corporate law.

Economics in Securities Fraud Cases: Applications at the Securities and Exchange Commission, 49 Bus. Law. 545, 548, 572-77 (1994).

20. As Kenneth Lehn has noted, in what is perhaps the "ultimate compliment that a scholar can receive from his profession," there was a marked decline in citations to Manne's article on mergers in the Journal of Financial Economics (the "predominant finance journal [publishing] papers on corporate control") as the number of publications on takeovers exponentially increased, suggesting that "the ideas espoused by Manne in 1965 [were] now so commonly accepted by financial economists" that they did not feel the need to cite anything in support of those propositions as they had in earlier years when the transactions were novel, the litcrature new, and the article was frequently cited. Kenneth R. Lchn, Some Observations on Henry Manne's Contributions to Financial Economics, 5o Case W. Res. L. Rev. 263, 266 (1999).

2I. Frank H. Easterbrook and Daniel R. Fischel, The Economic Structure of the Corporation (Cambridge, Mass., 1991). 


\section{Implications of the Revolution in Corporate Law for Legal Education}

The revolution in corporate law affects all aspects of business law education. I will focus on implications for the law school curriculum, law schools' relation with other units of the university in which they are situated, and law schools' relation with the practice of business law.

\section{Curriculum}

As I hope is evident from the earlier discussion, the transformation in legal scholarship and practice created a need for technical proficiency on the part of business lawyers and teachers. With regard to the future, the level of technical proficiency in finance and economics will surely only be greater than presentday requirements. In response to these developments, law schools have added courses on corporate finance and mergers and acquisitions (often referred to as deals courses) to their curriculum. But that response, in my judgment, is thoroughly inadequate.

The central problem is that those newer courses combined with other courses in the typical law school curriculum do not provide the technical level of knowledge that business lawyers need to master to be at the forefront of their profession. ${ }^{22}$ Law schools are not well-positioned to provide that knowledge on their own: most law faculties do not have the staffing to offer, for instance, the requisite class sections of finance, accounting, and so forth; they often barely manage to staff the introductory and a few advanced corporate law courses with tenure track faculty. Some law firms provide instruction in accounting, and some consulting firms offer mini-business school programs for new employees who lack an MBA, but the typical law firm-level resolution to this problem is best characterized as a sink or swim approach.

A cavalier response might be that law students are bright and they can learn what they need to know on the job, rationalizing the institutional indifference to the situation. Such a flippant answer can most politely be characterized as misguided, less politely as silly. It is plainly not tenable for a professional school to refuse to meet its obligation to educate individuals for their profession. If that is not central to its mission, then what is? In due course a law school that chose to follow such a path would find its reputation in a downward spiral. Yes, law students are bright and much can be learned on the job; but we are failing them when we do not provide them with the opportunity to master the essential knowledge they need for having successful careers, particularly hard-to-master knowledge that is neither easily nor quickly mastered on one's own. If you think I am overdramatizing the situation, ask yourself, how many autodidacts in the accounting or finance profession have you met lately? While the best business lawyers do not need to become financial economists

22. It goes without saying that the education is inadequate for a career in business, which some law school graduates pursue, but such preparation does not go to a law school's core educational mission. 
or accountants, they need a thorough working knowledge and mastery of the concepts and the relevant literature.

It is also not a satisfactory response to shrug off the problem by acknowledging that there are likely to be gaps in law school graduates' knowledge conccrning the legal landscape as substantial as those in their technical business knowledge. For, I believe, on-the-job-training can more successfully address the former gap. In short, law schools are doing a poor job when it comes to educating the preeminent business lawyers of the next generation and the fact that hardly any school is doing a particularly good job is no excuse. We ought to do something about this unacceptable situation. Simply put, the law school curriculum has not caught up with the transformation in the profession and legal scholarship.

But it is also not the comparative advantage of law schools to provide the sort of general business education that the contemporary business lawyer requires to be able to offer the highest quality service to clients and society. The most straightforward solution lies in actively encouraging students sceking a business law career to enroll in joint degree programs with management schools. Yet, widespread implementation of this solution is currently not feasible because the student must forgo a year of employment and incur an additional year of tuition in the existing joint degree program framework, a costly impediment to most individuals' enrollment. Obtaining the necessary knowledge without being in such a program is also a non-starter because it is difficult, sometimes impossible, for a non-joint degree student to enroll in core management school courses. Enrollment in those classes is typically capped, so that management schools can better educate their own students. And law schools, following ABA strictures, limit the number of non-law school courses that can be taken for credit. Furthermore, it would be, in my judgment, both infeasible and unwise to attempt to change a law school's character by making numerous appointments to staff those types of courses in the law school instead.

This curriculum failure has a straightforward solution that does not require altering the character or organization of law schools: greater integration of the law school business law and management school curriculums through the development of a more streamlined JD-MBA joint degree program than exists at present. In such a program, students would acquire the two degrees in three rather than four ycars. Northwestern University has recently established just such a program. The ABA's recent modest increase in the required number of law school credit hours should have no impact on this type of program, but other clarifying changes in credit rules, which require law schools to permit students to graduate in five semesters, will quite likely encourage schools to emulate Northwestern's lead in establishing such a program. I am convinced 
that such a program offers the most promising route for the education of the next generation of the leading business lawyers.

There are alternatives to the solution that I am advocating to the business law curriculum problem with which other law schools have been experimenting. Some law schools, for example, offer certificates in law and business, programs in which law students take a set of specified courses at the affiliated management school. ${ }^{23}$ While these programs are a step in the right direction from the standard law school business law curriculum, the specified course lists do not always include the requisite skills courses (or are structured so that students need not take those courses). A streamlined joint-degree program is, in my judgment, preferable for ensuring that students obtain both essential technical knowledge for a successful business law career and a richer and deeper understanding of the business world than is possible through the subset of business school courses in a certificate program. Of course, the more courses a certificate program requires, the less important the distinction between such a program and a streamlined (three-year) joint-degree program. Certificate programs make sense as a time saver when compared to a conventional fouryear joint-degree program, but not when compared to an accelerated program completed over three years.

The University of Virginia law school has followed a different approach, creating a law and business program that requires a course in accounting and finance (offered in the law school) and thereafter provides students in that track with deals-oriented courses. While this interesting innovation bears watching, it concentrates on providing legal skills with less focus on technical foundations. In my opinion the preferred balance of course work is the reverse, because the legal knowledge, as earlier noted, is more easily acquired on the job than technical business knowledge and, as is true of clinical education more generally, it is an expensive, labor intensive form of instruction. ${ }^{24}$

23. The New York University and University of Pennsylvania law schools offer such certificate programs, for instance, in which law students take five and three courses, respectively, from a list of approved courses at the Stern and Wharton business schools. The NYU program also has a summer component in which students take $g$ credits of courses covering economics, finance, and statistics; and LL.M. students as well as J.D. students participate.

24. For a discussion touching on the cost of implementing transactions-oriented courses see Victor Fleischer, Deals: Bringing Corporate Transactions into the Law School Classroom, 2002 Colum. Bus. L. Rev. 475 (2002). Changes in the organization of corporate law practice, suggested by the trend of associates leaving large firms often after only a brief stay, may well reduce the opportunity for young lawyers to receive on the job training: law firms will not invest in educating associates if they cannot recoup the investment. If this trend becomes pervasive, it may be necessary to include in the law school component of an accelerated JD-MBA, transactions-based courses. It should, of course, be noted that several law schools have been developing innovative transactions courses, see, e.g., Jonathan C. Lipson, Doing Deals in School, Business Law Today (Sept./Oct. 2005), at 51. The difference between those programs and the Virginia approach is twofold: Virginia requires technical skills training prior to enrollment in transaction-oriented courses, and those courses are not solely advanced seminars but also core corporate and commercial law courses in the business law track. 
The greater technical sophistication required of transactional lawyers will, in all likelihood, further advantage top-tier institutions in producing business lawyers, as those schools are better able to support financially joint-degree programs of the kind that I am advocating and that I believe to be the future: there is a financial cost to a law school from any joint-degree program, let alone a streamlined one (fewer semesters of tuition revenue than if the student obtains only a JD and thereby registers for six law school semesters). This dynamic also disadvantages stand-alone law schools, as well as law schools within universities without a management school, as they do not have an institution with which to affiliate easily.

The state of education for students seeking to pursue a career in business law teaching is, in my judgment, as troubling as that for those planning to enter business law practice. Paralleling the need to innovate upon existing JD-MBA programs, I believe that a new curricular initiative between law and management schools is essential to train business law teachers, a joint JD-PhD in finance. ${ }^{25} \mathrm{~A}$ law and finance $\mathrm{PhD}$ degree program would provide greater focus and structure than an economics $\mathrm{PhD}$ program, the program currently in place in many law schools (or a general business school PhD program), and should be especially useful for an empirical research agenda, which is where corporate law scholarship has moved over the last two decades.

My generation of corporate law academics, the first generation involved in the intellectual revolution, could get up to speed by auditing graduate courses in finance and econometrics: the field was new, and someone who had what by today's standards was a relatively primitive knowledge of finance and economics could make a contribution. A few in my generation, and an increasing number in the succeeding generation, have PhD's in economics as well as law degrees. But a problem with the latter route and the reason why creating degree programs with management schools is needed, is that an economics degree is not the best match for business law scholarship.

As earlier notcd, the building blocks of the revolution in corporate law originate most prominently in modern finance, a specialized field of economics. As a consequence, there is an imperfect match between the body of knowledge imparted in an economics $\mathrm{PhD}$ program and that which is critical for analyzing corporate law issues, and particularly for the direction in which the field has been moving, in which quantitative methods play a large part. Graduate economics department programs at most leading universities typically cmphasize theory, mathematical modeling, more than business school graduate programs, which, being professional schools, typically have a more applied bent, and joint degree candidates studying in economics programs, reflecting their training, invariably perceive that theory is a higher calling than empirical research.

25. We have just established such a program at Yale. The program pares down the requirements for the Ph.D. to the management school courses that provide the training that is most necessary for business law research-finance, microeconomics, financial accounting-eliminating valuable but more esoteric courses. 
Formal modeling has, in fact, played an important role in advancing legal scholarship and I should not be understood to be saying that it is not valuable. Rather, the present state of corporate law scholarship suggests to me that today there will be a lower likelihood of value added from pursuing formal modeling than from quantitative research. Much of the first generation's work was directed at using the intuitively graspable insights of finance and economics to analyze and rationalize the body of corporate law and to incorporate the new control transactions within it. Not surprisingly, that work often offered starkly divergent policy conclusions. More formal models following the earlier work have not appreciably advanced the policy debate. In fact, much of the more recent work is a straightforward replay, with more equations, of the rg8os literature debating the same issues. We are at a point where empirical research that facilitates the sorting out of theories will do more than further sophisticated modeling to advance the state of knowledge. This argues for a more applied, middle-range approach most consistent with what is emphasized in a management school $\mathrm{PhD}$ program. ${ }^{26}$

There are two important reasons why empirical research has caught on with contemporary corporate law scholars and will in all likelihood continue to do so for quite some time. First, policy disputes are, at least in principle, resolvable empirically when there is consensus on ends, as there is among most U.S. corporate law scholars since the field was transformed with the application of finance and the theory of the firm (a consensus that the objective of public, for-profit corporations is to maximize shareholder wealth). Second, empirical research has become far more accessible and cheaper to undertake than decades ago when the revolution in corporate law began. When I started law teaching over twenty years ago, I had to use a mainframe at the university computing center to access my data and the statistical programs that I was using to analyze the data; I had to pick up bulky reams of paper with my results, which sometimes were not available until the following day. Now one can do far more sophisticated statistical work at home on a personal computer, stock price data are directly downloadable from the web, powerful statistical programs run on PCs, the results are virtually instantaneously available, the statistics programs can be run interactively so one can immediately rerun analyses to refine hypotheses and do robustness checks, results can be input directly into word processing programs, and more. And virtually all of this is done with no university charge for computer time. Simply put, the cost of undertaking this kind of research has declined dramatically. Moreover, this line of research plays to the comparative advantage of law professors, who tend to be more steeped in institutional knowledge than most financial economists.

26. Readers of this article who are familiar with my own research agenda might note that what I have described and am advocating sounds a bit more than self-serving, as it is the style of my research. That is true. But this is the direction in which the field, for better or for worse, has been moving-many of the younger corporate law scholars today have been increasingly turning to undertake empirical research, at times working jointly with financial economists, and for the succeeding generation, the level of technical sophistication required for making a contribution will surely only increase. 


\section{Relations with Management Schools and the Profession}

The revolution in corporate law has further implications that concern the law school's relation with the rest of the university and the practice of business law. It should come as no surprise that with more sophisticated knowledge of finance and economics becoming the stock in trade, law school faculty in the corporate field often intellectually share more in common with management school faculty than with law school colleagues in non-business law areas. Law school and management school faculty are often studying similar issues using similar techniques. Indicia of this state of affairs are law and finance conferences organized jointly by law and business schools and publications of articles jointly authored by law and management school faculty.

The quantum leap in specialization and technical sophistication of the business law academic has important ramifications for law schools. It suggests that larger law school faculties and law schools associated with universities with management schools that have strong corporate finance groups (and good relations between the schools) will have a comparative advantage over smaller schools and those without such positive management school relations in recruiting business law faculty and in maintaining first-rate business law programs. This is because given the specialized nature of their research, corporate law academics will want to be part of a large business law group or to develop close ties with management school faculty to compensate for the more limited input that non-business law school colleagues can provide for improving their work. This phenomenon should be of particular concern to smaller elite law schools because it is doubtful that a school can maintain itself as a preeminent institution by becoming a niche school and ceding business law to its larger competitors.

What can schools with smaller-sized faculties do without changing their character and becoming large schools, beyond modestly increasing their business law faculty and encouraging cooperation with other units of their universities to be competitive in attracting quality business law scholars? One adaptive device to the new environment with which many schools have already been experimenting is the establishment of business law centers. The focus of these centers is to enhance the intellectual life of the law school in the business law area, and more specifically, to enhance the quality of faculty research and of students' educational experience by increasing exposure to and engagement with contemporary business law issues. Corporate law centers typically sponsor programs that invite business law faculty from other schools (as well as management school faculty) to share their research, thereby expanding, albeit temporarily, an in-house faculty group. While many law schools, and not only elite institutions, both large and small, have created such centers, I believe that there is more value added from having a center for smaller schools because a center's activities can mitigate the school's size disadvantage whilc the cost (in faculty time and resources) is not much greater for the small than for the large institution. 
Corporate law centers are very much works in progress and the scope of their functions is still being defined through innovation and experimentation. But there are two common foci of activities that I believe bear special notice as they will, in all likelihood, expand. First, many centers have sought to link up with distinguished alumni in a variety of formats, including conferences, colloquia, and more informal sessions. The intermediation between law schools and the profession assumed by the centers is a welcome trend that, it seems to me, will become of increased importance because as business law faculty move in the direction of greater technical sophistication, they run the risk of losing touch with the transactional issues of the day and thereby producing scholarship that will be arid and irrelevant. Centers are an ideal mechanism for keeping the academic community connected with new developments because the alumni who often generously support a center's activities and participate in the programs are also the best source for up-to-date transactional information.

Second, centers have a role, as yet still largely uncharted, in the steady internationalization of corporate law practice that we have observed for some time now. Comparative work on corporate governance is an active area of research in both law and finance, with corporate law and finance scholars in the United States, Europe, and Asia participating in numerous conferences and joint research activity. The boom in cross-border mergers and the concomitant rapid changes in corporate law regimes that have been occurring in Europe and Asia in recent years suggest that the research activities of business law centers will have a decidedly greater international and comparative focus.

The description of corporate law centers' programs presented thus far has emphasized the ways in which they foster faculty research; but it is important to note that the centers' programs have another important function for students. Many law schools have a large public law faculty presence and students who vigorously advocate expansion of public interest employment opportunities. These are perfectly fine developments. But students interested in business law can, in such a setting, feel left out or intellectually isolated. Whether or not such perceptions are accurate, corporate law center programs address such perceptions by offering intellectual engagement and support for that group of students, and provide the opportunity for students to project better what a successful business law career could be like by facilitating student-alumni interaction in an academic setting. My anecdotal observation is that such perceptions are mitigated by enrollment in JD-MBA joint degree programs, which focus students' energy and activity. While streamlining the joint degree program should help to mitigate that perception by increasing the number of students who consider such a program attractive, center programs should also aid in furthering a sense of belonging within the law school for all students interested in the business law area. 


\section{Conclusion}

I have tried in this article to describe the state of corporate law today and how we got here, and to suggest where we should be going. In the ig8os, corporate law scholarship and practice were completely transformed in response to intellectual currents in finance and economics and new transactional developments, which called for comprehensive legal innovation. Unfortunately, the law school curriculum has lagged far behind that revolution. The good news is that law schools can rectify this situation without having to make drastic changes. Law schools just need to be more proactive in the business law area concerning curricular initiatives, as experience has demonstrated that a less attentive approach will not do. 